\title{
Cropping systems, carbon sequestration and erosion in Brazil, a review ${ }^{1}$
}

\author{
Martial BernouX a*, Carlos C. CERRI ${ }^{\mathrm{b}}$, Carlos Eduardo P. CERRI ${ }^{\mathrm{b}}$, Marcos SiQueIRA NETO ${ }^{\mathrm{b}}$, Aurélie MetaYc, \\ Anne-Sophie PERrin ${ }^{\mathrm{a}}$, Eric SCOPEL ${ }^{\mathrm{d}}$, Tantely RAZAFIMBELO ${ }^{\mathrm{a}}$, Didier BlAVET ${ }^{\mathrm{a}}$, Marisa de C. PICCOLO ${ }^{\mathrm{b}}$, \\ Mariana PAVEI ${ }^{\mathrm{b}}$, Eleanor MILNE \\ ${ }^{a}$ IRD - UR SeqBio at Labo MOST, BP 64501, 34394 Montpellier Cedex 5, France \\ ${ }^{\mathrm{b}}$ CENA/USP, CP 96, 13400-970 Piracicaba - SP, Brazil \\ ${ }^{\mathrm{c}}$ CIRAD-AMIS-TA 40/01, 34398 Montpellier, France \\ ${ }^{\mathrm{d}}$ CIRAD-GEC, Brasilia, Brazil \\ e The Dept. of Soil Science, The University of Reading, PO Box 233, Reading, RG6 6DW, UK
}

(Accepted 15 December 2004)

\begin{abstract}
Soils represent a large carbon pool, approximately $1500 \mathrm{Gt}$, which is equivalent to almost three times the quantity stored in terrestrial biomass and twice the amount stored in the atmosphere. Any modification of land use or land management can induce variations in soil carbon stocks, even in agricultural systems that are perceived to be in a steady state. Tillage practices often induce soil aerobic conditions that are favourable to microbial activity and may lead to a degradation of soil structure. As a result, mineralisation of soil organic matter increases in the long term. The adoption of no-tillage systems and the maintenance of a permanent vegetation cover using Direct seeding Mulch-based Cropping system or DMC, may increase carbon levels in the topsoil. In Brazil, no-tillage practices (mainly DMC), were introduced approximately 30 years ago in the south in the Paraná state, primarily as a means of reducing erosion. Subsequently, research has begun to study the management of the crop waste products and their effects on soil fertility, either in terms of phosphorus management, as a means of controlling soil acidity, or determining how manures can be applied in a more localised manner. The spread of no-till in Brazil has involved a large amount of extension work. The area under no-tillage is still increasing in the centre and north of the country and currently occupies ca. 20 million hectares, covering a diversity of environmental conditions, cropping systems and management practices. Most studies of Brazilian soils give rates of carbon storage in the top $40 \mathrm{~cm}$ of the soil of 0.4 to $1.7 \mathrm{t} \mathrm{Cha}^{-\mathrm{P}}$ per year, with the highest rates in the Cerrado region. However, caution must be taken when analysing DMC systems in terms of carbon sequestration. Comparisons should include changes in trace gas fluxes and should not be limited to a consideration of carbon storage in the soil alone if the full implications for global warming are to be assessed.
\end{abstract}

no-tillage / mulch / stocks / fluxes / greenhouse gas / Brazil

\section{INTRODUCTION}

Concerns about global warming and increasing atmospheric greenhouse gas concentrations $\left(\mathrm{CO}_{2}, \mathrm{CH}_{4}\right.$ and $\left.\mathrm{N}_{2} \mathrm{O}\right)$ have led to questions on the role of soils as a source or sink of carbon (Houghton, 2003). Excluding carbonated rocks, soils constitute the largest surface carbon pool, approximately $1500 \mathrm{Gt}$, equivalent to almost three times the quantity stored in the terrestrial biomass and twice the amount stored in the atmosphere. Therefore, any modification of land use or land management can induce changes in soil carbon stocks, even in agricultural systems in which carbon is perceived to be in a steady state (Lal et al., 1997; Six et al., 2002).

No-tillage is presumed to be the oldest system of soil management. In some parts of the tropics, no-tillage is still practised as part of slash-and-burn agriculture. After clearing an area of forest, by controlled burning, seed is placed directly into the soil. However, as mankind developed more systematic agricultural systems, cultivation of the soil became an accepted prac- tice as a means of preparing a more suitable environment for plant growth. Paintings in ancient Egyptian tombs portray farmers tilling their fields using a swing-plough and oxen, prior to planting. Indeed, tillage as symbolised by the mouldboard plough became almost synonymous with agriculture (Dick and Durkalski, 1997). No-tillage can be defined as a crop production system where soil is left undisturbed from harvest to planting except for fertiliser application.

In the southern part of Brazil, no-tillage was developed in response to soil erosion problems and declining levels of land productivity under "conventionally" tilled systems. The underlying land management principles that led to the development of no-tillage systems were: prevention surface sealing caused by rainfall impact, achievement and maintenance of an open soil structure and reduction of the volume and velocity of surface runoff. Consequently, the no-tillage strategy was based on two essential farm practices: (i) not tilling and (ii) keeping soil covered at all times. The particular no-tillage system

\footnotetext{
* Corresponding author: martial.bernoux@mpl.ird.fr

1 This article has been presented at the Colloquium of Montpellier entiled "Land use, Erosion \& Carbon Sequestration" organized by the "Réseau Érosion Francophone" and the Lab. MOST of IRD and CIRAD (information: Dr. Eric Roose, Eric.Roose@ird.mpl.fr).
} 
considered in this paper is referred to as 'a direct seeding mulchbased cropping system' (referred to here as DMC).

Farming methods that use mechanical tillage, such as the mouldboard plough, secondary tillage tools for seedbed preparation or disking for weed control, can cause soil carbon loss by several mechanisms: (1) by disrupting soil aggregates, which protect soil organic matter from decomposition (Karlen and Cambardella, 1996; Six et al., 1999); (2) by stimulating short-term microbial activity through enhanced aeration, resulting in increased net release of $\mathrm{CO}_{2}$ and other gases to the atmosphere (Bayer et al., 2000a, b; Kladivko, 2001), and (3) by mixing fresh residues into the soil where conditions for decomposition are often more favourable than on the surface (Karlen and Cambardella, 1996; Plataforma Plantio Direto, 2003). Furthermore, conventional tillage can leave soils more prone to erosion, resulting in further loss of soil carbon (Lal, 2002). DMC practices, however, reduce soil disturbance and often result in a significant accumulation of soil carbon (Sá et al., 2001; Schuman et al., 2002) and consequently a reduction of gas emissions, especially $\mathrm{CO}_{2}$ (Lal, 1998; Paustian et al., 2000). Furthermore, in Brazilian conditions, the possibility of an earlier seeding date with direct seeding often enables a second crop cycle with a commercial or cover crop. Consequently, more biomass is returned to the system each year. Despite this, there is considerable evidence that the main effect in terms of carbon storage, of no-tillage systems, is seen in the topsoil with little overall effect at deeper layers (Six et al., 2002).

The objective of this paper is to provide a synthesis of the effects of DMC on carbon sequestration and erosion in Brazil.

\section{THE EXPANSION OF NO-TILLAGE IN BRAZIL}

The history of DMC started in the south of Brazil. The first scientific no-tillage experiment was conducted in 1969 by the Federal University of Rio Grande do Sul in the southern part of the country on an area of 1 ha; however, the trial was interrupted by the accidental destruction of the no-tillage seeding machine after the first seeding (Borges Filho, 2001). Several other studies were set up at the beginning of the 1970s in Parana state near Londrina and Ponta Grossa (Borges Filho, 2001; Sá et al., 2001; Six et al., 2002). The effectiveness of no-tillage systems at controlling soil erosion and reducing costs encouraged farmers in Parana State to take up the practice. This uptake corresponded with the release of modern herbicides, such as glyphosates, in the 1970s, which made no-tillage systems easier to manage. During the crop year 1974/75, DMC systems were adopted by approximately 235 farms, (representing ca. 16500 ha of cultivated land) in Parana State. Until the end of the 1970s the spread of DMC was slow and limited to Parana and Rio Grande do Sul, mainly due to a lack of technical assistance and a lack of studies demonstrating the advantages of DMC. At the beginning of the 1980s, producers began to organise themselves into associations to promote DMC, the most well known being the "Clube da Minhoca" (literally meaning "The Earthworm Club") and the "Clubes Amigos da Terra" (The Friends of the Soil Clubs) (Borges Filho, 2001).

In the Cerrado regions (the central area of Brazil covered mainly by Savannah), DMC was imported from the south at the beginning of the 1980s. However, the systems had to be adapted

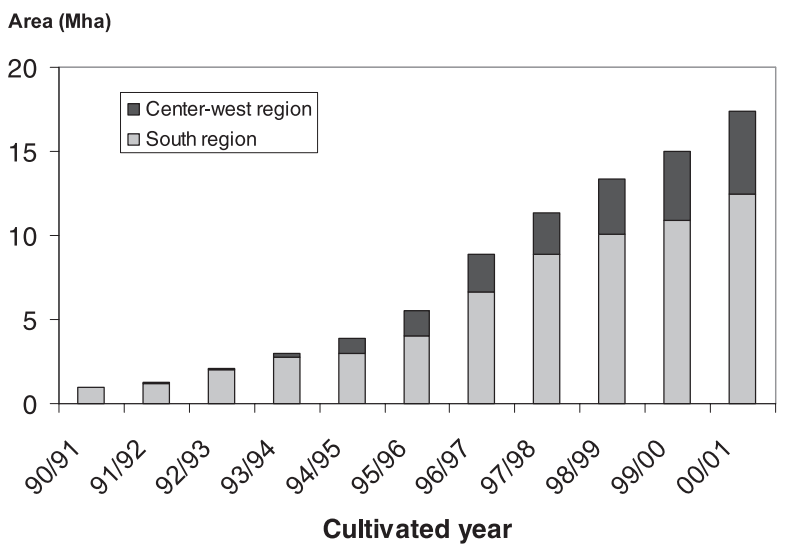

Figure 1. Cultivated area under direct seeding mulch-based cropping (DMC) systems in Brazil. Adapted from Febrapdp (2004).

somewhat in order to be applicable to this area. Winters in the Cerrado region are dryer and hotter than in the south and summers are hot and humid, inducing a rapid rate of crop residue decomposition. One of the first trials involving DMC was carried out in 1981 in Rio Verde in Goiás State, by Eurides Penha. Penha seeded 200 ha of soybean on soybean residues from the previous crop. The year after, another farmer tried DMC systems with soybean and maize in Santa Helena de Goiás, a neighbouring city (Borges Filho, 2001). In the beginning, the expansion of DMC was slow and only really began to accelerate at the end of the 1980s. During the cropping year 1991/92 the area under DMC in the Cerrado region was approximately 180000 ha, representing $13.3 \%$ of the total land under DMC in Brazil. From the early 1990s onwards, the rate of expansion of DMC in the Cerrado region became faster than in the rest of Brazil (Fig. 1).

At present, approximately 63 million ha are under no-tillage systems throughout the world, with the USA having the largest area ( 21.1 million ha) (Derpsch, 2001). The 20 million ha covered by DMC in Brazil (Feprapdp, 2004) make the country the second largest adopter of the practice in the world. The expansion of DMC in Brazil has taken place not only as a result of the conversion from conventional tillage in the southern region (72\%), but also following the clearing of natural savannah in the central-western area (28\%). More recently, due to the high profit margins involved, ranchers in the Amazon region have started to convert old pastures into soybean/millet DMC systems. During the cropping year 2000/01 DMC systems dominated in the southern region (Parana - 5 Mha, Rio Grande do Sul - 3.6 Mha and Santa Catarina - 1 Mha) and the Cerrado region (4.9 Mha), and was also significant in Mato Grosso do Sul (1.7 Mha) and São Paulo State (1 Mha).

\section{CARBON SEQUESTRATION}

For the purpose of this review the term 'carbon sequestration' is used according to the definition given by Bernoux et al. (2005). "Soil carbon sequestration", for a specific agro-ecosystem in comparison with a reference one, should be considered as the result (for a given period of time and portion of space) 
of the net balance of all greenhouse gases, expressed in $\mathrm{C}-\mathrm{CO}_{2}$ equivalent or $\mathrm{CO}_{2}$ equivalent, computing all emission sources at the soil-plant-atmosphere interface, and also all the indirect fluxes (gasoline, enteric emissions, etc.). When comparing a DMC system with a conventional tillage system this means that not only is carbon storage taken into account, but the resulting greenhouse gas fluxes such as $\mathrm{N}_{2} \mathrm{O}$ and $\mathrm{CH}_{4}$ at the field and farm level are also taken into account.

\subsection{No-tillage, conventional tillage and carbon storage}

Lindstrom et al. (1998) reported that globally, conservation or reduced tillage can store $0.1-1.3 \mathrm{t} \mathrm{C} \mathrm{ha}^{-1} \mathrm{yr}^{-1}$ and could feasibly be adopted on up to 60 percent of arable lands. These estimates depend on continued use of conservation tillage. Use of intensive tillage or mouldboard ploughing can negate or offset any gains made in carbon sequestration.

Changes in soil carbon stocks under no-tillage have been estimated in earlier studies for temperate and tropical regions. Cambardella and Elliott (1992) showed an increase of $6.7 \mathrm{t} \mathrm{C} \mathrm{ha}^{-1}$ in the top $20 \mathrm{~cm}$ in a wheat-fall rotation system after 20 years of no-tillage, compared with conventional tillage. Reicosky et al. (1995) reviewed various publications and found that organic matter increased under conservation management systems with rates ranging from 0 to $1.15 \mathrm{t} \mathrm{C} \mathrm{ha}^{-1} \mathrm{yr}^{-1}$, with the highest accumulation rates generally occurring in temperate conditions. Lal et al. (1998) calculated a carbon accumulation rate of 0.1 to $0.5 \mathrm{t} \mathrm{Cha}^{-1} \mathrm{yr}^{-1}$ in temperate regions. For the tropical west of Nigeria, Lal (1997) observed a $1.33 \mathrm{t} \mathrm{C} \mathrm{ha}^{-1}$ increment during 8 years under no-tillage as compared with the conventional tillage of maize, which represents an accumulation rate of $0.17 \mathrm{t} \mathrm{C} \mathrm{ha}^{-1} \mathrm{yr}^{-1}$. More recently, a review by Six et al. (2002) reported that in both tropical and temperate soils, a general increase in carbon levels $\left(325 \pm 113 \mathrm{~kg} \mathrm{C} \mathrm{ha}^{-1} \mathrm{yr}^{-1}\right)$ was observed under no-tillage systems compared with conventional tillage.

In the tropics, specifically in Brazil, estimates of the rate of carbon accumulation have generally been restricted to the two main regions under DMC (the south and central west). In the southern region, Sá (2001) and Sá et al. (2001) estimated a greater accumulation rate $\left(0.8 \mathrm{tC} \mathrm{ha}^{-1} \mathrm{yr}^{-1}\right.$ in the $0-20 \mathrm{~cm}$ layer and $0.9 \mathrm{t} \mathrm{C} \mathrm{ha}^{-1} \mathrm{yr}^{-1}$ in the $0-40 \mathrm{~cm}$ layer) after 22 years under DMC compared with the same period under conventional tillage. The authors mentioned that accumulated carbon was generally greater in the coarse $(>20 \mu \mathrm{m})$ than in the fine $(<20 \mu \mathrm{m})$ particle-size fraction, indicating that most of this additional carbon is weakly stable. Bayer et al. (2000a, b) found a carbon accumulation rate of $1.6 \mathrm{t} \mathrm{ha}^{-1} \mathrm{yr}^{-1}$ for a 9-year DMC system compared with $0.10 \mathrm{t} \mathrm{ha}^{-1} \mathrm{yr}^{-1}$ for the conventional system in the first $30 \mathrm{~cm}$ layer of an Acrisol, in the southern part of Brazil. Corazza et al. (1999) reported an additional accumulation of approximately $0.75 \mathrm{t} \mathrm{C} \mathrm{ha}^{-1} \mathrm{yr}^{-1}$ in the $0-40 \mathrm{~cm}$ soil layer due to no-tillage, in the Cerrado region located in the central west. Estimates by Amado et al. $(1998,1999)$ indicated an accumulation rate of $2.2 \mathrm{t} \mathrm{ha}^{-1} \mathrm{yr}^{-1}$ of soil organic carbon in the first $10 \mathrm{~cm}$ layer. Other studies considering no-till systems carried out in the central-western part of Brazil (Castro Filho et al., 1998, 2002; Lima et al., 1994; Peixoto et al., 1999; Resck et al., 2000; Riezebos and Loerts, 1998) reported soil carbon accumulation rates due to no-tillage varying from 0 to $1.2 \mathrm{t} \mathrm{C} \mathrm{ha}^{-1} \mathrm{yr}^{-1}$ for the 0-10 $\mathrm{cm}$ layer.

More detailed accumulation rates are reported in Table I. Rates are organised by region and are derived from published and unpublished material. In the Cerrado region carbon accumulation rates vary from 0.4 to $1.7 \mathrm{t} \mathrm{C} \mathrm{ha}^{-1}$ for the $0-40 \mathrm{~cm}$ layer, which is similar to the range found in the southern region $\left(-0.5\right.$ to $\left.0.9 \mathrm{tC} \mathrm{ha}^{-1}\right)$. Mean rates of carbon storage were similar among "Cerrado" $\left(0.65 \mathrm{t} \mathrm{C} \mathrm{ha}^{-1}\right)$, "South" $\left(0.68 \mathrm{t} \mathrm{C} \mathrm{ha}^{-1}\right)$, and "Other" $\left(0.60 \mathrm{t} \mathrm{C} \mathrm{ha}^{-1}\right)$ regions, when the soil surface layer was considered $(0-20 \mathrm{~cm})$. More variability was found in the southern region $\left(-0.07\right.$ to $\left.1.6 \mathrm{t} \mathrm{C} \mathrm{ha}^{-1}\right)$ for the $0-20 \mathrm{~cm}$ layer than in the other regions. However, it is important to mention that these mean values aggregate different soil and crop types and the variability is high. For instance, the mean value of $0.68 \mathrm{t} \mathrm{C} \mathrm{ha}^{-1}$ for the southern region was obtained by averaging 15 observations (Tab. I) and the associated standard deviation is $0.54 \mathrm{t} \mathrm{C} \mathrm{ha}^{-1}$.

Some studies performed in Brazil reported that organic carbon (OC) contents under DMC and conventional systems can be very similar (Corazza et al., 1999; Freixo et al., 2002; Roscoe and Buurman, 2003; Sisti et al., 2004). Sisti et al. (2004) reported that the soil under native vegetation (measured in areas neighbouring the experimental site) had a high carbon and nitrogen content ( $37 \mathrm{~g} \mathrm{C}$ and $3.1 \mathrm{~g} \mathrm{~N}$ per kg soil) in the first $5 \mathrm{~cm}$ depth. Carbon and nitrogen contents declined to approximately half these values in the $10-15 \mathrm{~cm}$ layer. The carbon concentration in the top $5 \mathrm{~cm}$ of soil was considerably higher in all three rotations managed with DMC compared with the conventional system, although not as high as under the native forest. Machado and Silva (2001) showed decreases in SOC of $23.4 \%$ and $47.8 \%$, respectively, at $0-5 \mathrm{~cm}$ depth for DMC and conventional tillage systems, when compared with an adjacent non-cultivated area. The study was carried out on an Oxisol in the south of Brazil, following 11 years of soybean-wheat cultivation. However, the authors also found SOC in the $0-40 \mathrm{~cm}$ layer to be the same as the forest soil for both DMC and conventional tillage.

Another important point when comparing soil carbon stocks in DMC and conventional systems is to avoid comparing superficial layers such as $0-5 \mathrm{~cm}$ and $0-10 \mathrm{~cm}$. In conventional systems involving tillage, homogenisation occurs in the first $20 \mathrm{~cm}$ and thus a superficial layer cannot be compared directly without bias.

\subsection{Fluxes of other greenhouse gases}

Increasingly, attention is being focused on the relationship between atmospheric carbon dioxide concentrations and carbon concentrations in soil. Carbon dioxide makes the largest contribution to climate change simply because of its abundance in the atmosphere compared with other greenhouse gases. Changes in farming practices, such as altering tillage intensity and crop rotations, may alter carbon sequestration in the soil and thereby help to alleviate carbon dioxide accumulation in the atmosphere. However, fluxes of other greenhouse gases such as $\mathrm{N}_{2} \mathrm{O}$ and $\mathrm{CH}_{4}$ at the field and farm level may be altered by DMC. Six et al. (1999) reported that $\mathrm{CH}_{4}$ uptake increased $\left(0.42 \pm 0.10 \mathrm{~kg} \mathrm{C}^{-} \mathrm{CH}_{4} \mathrm{ha}^{-1} \mathrm{yr}^{-1}\right)$ and $\mathrm{N}_{2} \mathrm{O}$ emissions increased

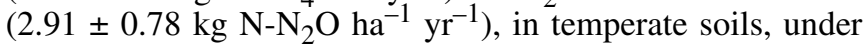


Table I. Carbon storage rates. Accumulation following conversion of a conventional tillage system to DMC in direct seeding mulch-based cropping (DMC) systems in Brazil.

\begin{tabular}{|c|c|c|c|c|c|c|c|c|}
\hline Place & State $^{\mathrm{a}}$ & $\begin{array}{l}\text { Succession or dominant } \\
\text { plant }^{\mathrm{b}}\end{array}$ & $\begin{array}{l}\text { Reported soil } \\
\text { classification }\end{array}$ & Clay $(\%)$ & $\begin{array}{l}\text { Layer } \\
(\mathrm{cm})\end{array}$ & Duration (yr) & $\begin{array}{l}\text { Rate } \\
\text { (t C/ha) }\end{array}$ & Source \\
\hline \multicolumn{9}{|c|}{ Cerrados region } \\
\hline \multirow[t]{2}{*}{ Planatina } & DF & $\mathrm{S} / \mathrm{W}$ & Latossol (Oxisol) & $40-50$ & $0-20$ & 15 & 0.5 & Corazza et al., 1999 \\
\hline & & & & & $0-40$ & 15 & 0.8 & \\
\hline Sinop & MT & $\mathrm{R}-\mathrm{S} / \mathrm{So}-\mathrm{R} / \mathrm{So}-\mathrm{S} / \mathrm{M}-\mathrm{S} / \mathrm{E}$ & Latossol (Oxisol) & $50-65$ & $0-40$ & 5 & 1.7 & Perrin, 2003 \\
\hline Goiânia & GO & Rice/Soya & Dark red Latossol & & $0-10$ & 5 & 0.7 & ud \\
\hline Rio Verde & GO & $\begin{array}{l}\text { M or S/Fallow } \\
\text { S/M or So or Mi }\end{array}$ & Red Latossol & $45-65$ & $0-20$ & 12 & 0.8 & Scopel et al., 2003 \\
\hline Not specified & $?$ & $\mathrm{M}$ or $\mathrm{S}$ & $\begin{array}{l}\text { Dark Red Latossol } \\
\text { (Oxisol) }\end{array}$ & $>30$ & $0-40$ & 16 & 0.4 & Resck et al., 2000 \\
\hline \multicolumn{9}{|c|}{ Southern region } \\
\hline \multirow[t]{3}{*}{ Londrina } & PR & $\mathrm{W} / \mathrm{S}$ & Oxisol & & $0-10$ & 22 & 0.31 & Machado and Silva, 2001 \\
\hline & & & & & $0-20$ & 22 & 0.25 & \\
\hline & & & & & $0-40$ & 22 & -0.17 & \\
\hline Londrina & PR & $\mathrm{S} / \mathrm{W}-\mathrm{S} / \mathrm{L}-\mathrm{M} / \mathrm{O}$ & Red Latossol & & $0-20$ & 7 & $0.5-0.9$ & Zotarelli et al., 2003 \\
\hline \multirow[t]{2}{*}{ Londrina } & PR & $\mathrm{S} / \mathrm{W} / \mathrm{S}$ or $\mathrm{M} / \mathrm{W} / \mathrm{M}$ or $\mathrm{S} / \mathrm{W} / \mathrm{M}$ & $\begin{array}{c}\text { Oxisol } \\
\text { Typic Haplorthox }\end{array}$ & & $0-10$ & 14 & $0.4^{\mathrm{d}}$ & Castro Filho et al., 1998 \\
\hline & & & & & $0-20$ & & $0.2^{\mathrm{d}}$ & \\
\hline Londrina & PR & $\mathrm{S} / \mathrm{W} / \mathrm{S}$ or $\mathrm{M} / \mathrm{W} / \mathrm{M}$ or $\mathrm{S} / \mathrm{W} / \mathrm{M}$ & $\begin{array}{c}\text { Oxisol } \\
\text { Typic Haplorthox }\end{array}$ & & $0-40$ & 21 & $0^{\mathrm{c}}$ & Corazza Filho et al., 2002 \\
\hline Ponta Grossa & PR & $(\mathrm{S}$ or $\mathrm{M}) /(\mathrm{O}$ or $\mathrm{W})$ & $\begin{array}{c}\text { Oxisol } \\
\text { Typic hapludox }\end{array}$ & $40-45$ & $0-40$ & 22 & 0.9 & Sá et al., 2001 \\
\hline Tibagi & PR & $(\mathrm{S}$ or $\mathrm{M}) /(\mathrm{O}$ or $\mathrm{W})$ & $\begin{array}{c}\text { Oxisol } \\
\text { Typic hapludox }\end{array}$ & $40-45$ & $0-40$ & 10 & -0.5 & Sá et al., 2001 \\
\hline Tibagi & PR & $\mathrm{M} / \mathrm{W}-\mathrm{S} / \mathrm{O}-\mathrm{S} / \mathrm{O}$ & $\begin{array}{l}\text { Red Latossol } \\
\text { Oxisol }\end{array}$ & $40-45$ & $0-10$ & 22 & $1.0^{\mathrm{d}}$ & Venzke Filho et al., 2002 \\
\hline Tibagi & PR & $\mathrm{M} / \mathrm{W}-\mathrm{S} / \mathrm{O}-\mathrm{S} / \mathrm{O}$ & $\begin{array}{l}\text { Red Latossol } \\
\text { Oxisol }\end{array}$ & 42 & $0-20$ & 10 & 1.6 & Siqueira Neto, 2003 \\
\hline \multirow[t]{2}{*}{ Toledo } & PR & $\mathrm{S} / \mathrm{O}$ & Haplic Ferrasol & & $0-10$ & 3 & $-0.68^{\mathrm{d}}$ & Riezebos and Loerts, 1998 \\
\hline & & $\mathrm{S} / \mathrm{O}$ & Haplic Ferrasol & & $0-10$ & 10 & $0.37^{\mathrm{d}}$ & \\
\hline \multirow[t]{3}{*}{ Passo Fundo } & $\mathrm{RS}$ & $\mathrm{W} / \mathrm{S}$ & Oxisol & & $0-10$ & 11 & 0.59 & Machado and Silva, 2001 \\
\hline & & & & & $0-20$ & 11 & -0.07 & \\
\hline & & & & & $0-40$ & 11 & 0.29 & \\
\hline \multirow[t]{3}{*}{ Passo Fundo } & $\mathrm{RS}$ & $\mathrm{W} / \mathrm{S}$ & $\begin{array}{l}\text { Red Latossol } \\
\text { Typic hapludox }\end{array}$ & 63 & $0-30$ & 13 & $0^{\mathrm{c}}$ & Sisti et al., 2004 \\
\hline & & $\mathrm{W} / \mathrm{S}-\mathrm{V} / \mathrm{M}$ & & & $0-30$ & 13 & 0.4 & \\
\hline & & $\mathrm{W} / \mathrm{S}-\mathrm{O} / \mathrm{S}-\mathrm{V} / \mathrm{M}$ & & & $0-30$ & 13 & 0.7 & \\
\hline \multirow[t]{6}{*}{ Passo Fundo } & $\mathrm{RS}$ & $\mathrm{W} / \mathrm{S}$ & $\begin{array}{l}\text { Red Latossol } \\
\text { Typic hapludox }\end{array}$ & 63 & $0-10$ & 11 & 0.3 & Freixo et al., 2002 \\
\hline & & & & & $0-20$ & 11 & $0^{\mathrm{c}}$ & \\
\hline & & & & & $0-30$ & 11 & $0^{\mathrm{c}}$ & \\
\hline & & $\mathrm{W} / \mathrm{S}-\mathrm{W} / \mathrm{M}$ & $\begin{array}{l}\text { Red Latossol } \\
\text { Typic hapludox }\end{array}$ & & $0-10$ & 11 & 0.4 & Freixo et al., 2002 \\
\hline & & & & & $0-20$ & 11 & 0.2 & \\
\hline & & & & & $0-30$ & 11 & $0^{\mathrm{c}}$ & \\
\hline
\end{tabular}


Table I. Continued.

\begin{tabular}{|c|c|c|c|c|c|c|c|c|}
\hline Place & State $^{\mathrm{a}}$ & $\begin{array}{c}\text { Succession or dominant } \\
\text { plant }^{\mathrm{b}}\end{array}$ & $\begin{array}{l}\text { Reported soil } \\
\text { classification }\end{array}$ & Clay $(\%)$ & $\begin{array}{l}\text { Layer } \\
(\mathrm{cm})\end{array}$ & Duration (yr) & $\begin{array}{c}\text { Rate } \\
\text { (t C/ha) }\end{array}$ & Source \\
\hline Santa Maria & $\mathrm{RS}$ & $\mathrm{M}$ and $\mathrm{Mu} / \mathrm{M}$ & Ultisol & 15 & $0-20$ & 4 & 1.3 & Amado et al., 2001 \\
\hline \multirow[t]{3}{*}{ Eldorado do Sul } & $\mathrm{RS}$ & $\mathrm{M} / \mathrm{G}$ & $\begin{array}{c}\text { Podzólico } \\
\text { vermelho escuro }\end{array}$ & & $0-17.5$ & 5 & $1.4^{\mathrm{d}}$ & Testa et al., 1992 \\
\hline & & $\mathrm{M} / \mathrm{La}$ & & & $0-17.5$ & 5 & $0.6^{\mathrm{d}}$ & \\
\hline & & $\mathrm{O} / \mathrm{M}$ & & & $0-17.5$ & 5 & $0.2^{\mathrm{d}}$ & \\
\hline Eldorado do Sul & $\mathrm{RS}$ & $\mathrm{O}+\mathrm{V} / \mathrm{M}+\mathrm{C}$ & $\begin{array}{l}\text { Clay loam Acrisol } \\
\text { Typic Paleudult }\end{array}$ & 22 & $0-17.5$ & 9 & 0.84 & Bayer et al., 2002 \\
\hline \multirow[t]{2}{*}{ Eldorado do Sul } & $\mathrm{RS}$ & $\mathrm{O} / \mathrm{M}$ & $\begin{array}{l}\text { Clay loam Acrisol } \\
\text { Typic Paleudult }\end{array}$ & 22 & $0-30$ & 9 & 0.51 & Bayer et al., 2000b \\
\hline & & $\mathrm{O}+\mathrm{V} / \mathrm{M}+\mathrm{C}$ & & & $0-30$ & 9 & 0.71 & \\
\hline Eldorado do Sul & $\mathrm{RS}$ & $\mathrm{O}+\mathrm{V} / \mathrm{M}+\mathrm{C}$ & $\begin{array}{l}\text { Clay loam Acrisol } \\
\text { TypicPaleudult }\end{array}$ & 22 & $0-17.5$ & 12 & 1.26 & Bayer et al., 2000a \\
\hline Lages & $\mathrm{SC}$ & $\mathrm{M}$ or $\mathrm{S} / \mathrm{W}$ or $\mathrm{O}$ & Cambissol & & $0-20$ & 8 & 1.0 & Bayer and Bertol, 1999 \\
\hline \multicolumn{9}{|l|}{ Other regions } \\
\hline \multirow[t]{2}{*}{ Campinas } & SP & $\mathrm{S}$ or $\mathrm{C} / \mathrm{M}$ & $\begin{array}{l}\text { Rhodic Ferralsol } \\
\text { Typic Haplorthox }\end{array}$ & 60 & $0-20$ & 3 & $0.8^{\mathrm{de}}$ & De Maria et al., 1999 \\
\hline & & & & & $0-20$ & 8 & $0.4^{\mathrm{de}}$ & \\
\hline \multirow[t]{2}{*}{ Sete Lagoas } & MG & $\mathrm{M} / \mathrm{B}$ & $\begin{array}{l}\text { Dark red Latossol } \\
\text { Typic Haplustox }\end{array}$ & & $0-15$ & 10 & $0^{\mathrm{c}}$ & $\begin{array}{l}\text { Roscoe and Buurman, } \\
2003\end{array}$ \\
\hline & & & & & $0-45$ & & $0^{\mathrm{c}}$ & \\
\hline
\end{tabular}

${ }^{a}$ PR = Parana, RS = Rio Grande do Sul, DF = Distrito Federal, $\mathrm{SC}=$ Santa Catarina, $\mathrm{SP}=$ São Paulo, MT = Mato Grosso, GO = Goiás, MG = Minas Gerais $;{ }^{\mathrm{b}}$ Dominant succession: $\mathrm{W}=$ Wheat (triticum aestivum), $\mathrm{S}=$ Soybean $($ Glycine max), $\mathrm{So}=$ Sorghum $($ Sorghum vulgaris) $\mathrm{R}=\mathrm{Rice}($ Oriza sativa $)$, $\mathrm{E}=$ Eleusine coracana, $\mathrm{O}=$ Oat (Avena sativa), $\mathrm{V}=$ Vetch (Vicia sativa), $\mathrm{M}=$ Maize (Zea mays), B = Beans (Phaseolus vulgaris), Mu $=\mathrm{Mucuna}($ Stizolobium cinereum), $\mathrm{C}=$ cowpea (Vigna unguiculata), $\mathrm{L}=$ Lupine bean (Lupinus angustifollios), $\mathrm{La}=\mathrm{Lablabe}($ Dolicbos lablab), $\mathrm{G}=\mathrm{Guandu}($ Cajanus cajan); ${ }^{\mathrm{c}} 0$ means that the difference was not significant; ${ }^{\mathrm{d}}$ Calculated using an arbitrary soil bulk density of $1.2 \mathrm{~g} \mathrm{~cm}^{-3} ;{ }^{\mathrm{e}}$ value reported for OM, $\mathrm{C}=$ $\mathrm{OM} / 1.724, \mathrm{ud}=$ unpublished data from Metay.

no-tillage when compared with conventional tillage. These increased $\mathrm{N}_{2} \mathrm{O}$ emissions lead to a negative global warming potential of the DMC system when expressed on a $\mathrm{C}-\mathrm{CO}_{2}$ equivalent basis. Global warming potentials are measurements of the relative radiative effect of a given substance (in this case $\mathrm{CO}_{2}$ ) compared with another substance and integrated over a determined time period. For example, one $\mathrm{kg}$ of $\mathrm{CH}_{4}$ is as effective, in terms of radiative forcing, as $23 \mathrm{~kg}$ of $\mathrm{CO}_{2}$. On a carbon or nitrogen mass basis, $1 \mathrm{~kg}$ of C- $\mathrm{CH}_{4}$ is equivalent to $8.36 \mathrm{~kg}$ of $\mathrm{C}-\mathrm{CO}_{2}$ and $1 \mathrm{~kg}$ of $\mathrm{N}-\mathrm{N}_{2} \mathrm{O}$ to $126.86 \mathrm{~kg} \mathrm{C}-\mathrm{CO}_{2}$. The authors studied other changes induced by no-tillage and concluded that "from an agronomic standpoint no-tillage is beneficial, but from a global change standpoint more research is needed to investigate the interactive effects of tillage, fertilizer application methodology and crop rotation as they affect carbon accumulation, $\mathrm{CH}_{4}$-uptake and $\mathrm{N}_{2} \mathrm{O}$-fluxes, especially in tropical soils, where data on this matter is still lacking". This is particularly true for the $\mathrm{N}_{2} \mathrm{O}$ fluxes when legume crops are used as cover crops or green fertiliser, as some studies tend to show that $\mathrm{N}_{2} \mathrm{O}$ emissions may be enhanced as a result (Flessa et al., 2002; Giller et al., 2002)
Few results have been published regarding $\mathrm{N}_{2} \mathrm{O}$ emissions in tropical regions. Pinto et al. (2002) showed low $\mathrm{NO}$ and $\mathrm{N}_{2} \mathrm{O}$ emissions, low nitrification rates and the majority of inorganic $\mathrm{N}$ to be in the form of $\mathrm{NH}_{4}{ }^{+}$, all indicative of a conservative $\mathrm{N}$ cycle in the Cerrado. Passianoto et al. (2003) suggested that notillage regimes will result in lower $\mathrm{CO}_{2}$ emissions than degraded pastures, but higher $\mathrm{N}_{2} \mathrm{O}$ and $\mathrm{NO}$ emissions in Amazonia and that the addition of $\mathrm{N}$ fertiliser stimulates $\mathrm{N}_{2} \mathrm{O}$ and NO emissions. A recent study (Metay, 2004) compared the production and emission of $\mathrm{N}_{2} \mathrm{O}$ from two treatments: conventional tillage and DMC (no-tillage and direct sowing in the cover crop after weed-killer application). The main crop was rice (Oriza sativa) and the cover crop a fodder grass (Brachiaria) with a legume (Crotalaria). The experiment was established at "Embrapa Arroz e Feijão" field experiment station, in Santo Antonio de Goiás (Goiás State, Brazil) in 2002-2003. Data on climate, soil temperature, soil mineral nitrogen, soil moisture and soil carbon sequestration rates were monitored for more than one year as potential determinants of the greenhouse gas emissions. Twelve chambers in each of the treatments were used to measure greenhouse gas fluxes. Fluxes were measured 
twice a week. Chambers were sealed for 2 hours to allow gases to accumulate. The chamber atmosphere was sampled 5 times during this period in 13-mL vacuum container tubes that were previously purged of other gases. $\mathrm{N}_{2} \mathrm{O}$ fluxes were calculated by linear interpolation.

$\mathrm{N}_{2} \mathrm{O}$ concentrations in the soil atmosphere were determined using permanent gas samplers inserted into the soil at various depths $(10,20$ and $30 \mathrm{~cm})$. The results demonstrated that $\mathrm{N}_{2} \mathrm{O}$ emissions were very low $\left(<1 \mathrm{~g} \mathrm{ha}^{-1} \mathrm{day}^{-1}\right)$ for both systems. Peaks of $\mathrm{N}_{2} \mathrm{O}$ were observed after fertilisation. $\mathrm{N}_{2} \mathrm{O}$ is produced mainly by denitrification, which may be explained by low $\mathrm{NO}_{3}{ }^{-}$levels in soils and $\mathrm{a}<60 \%$ water-filled pore space (WFPS) within the soil for the majority of the time. Low WFPS under these crops can be caused by evaporation at high temperatures (more than or equal to $25^{\circ} \mathrm{C}$ ). However, measurements of gas concentrations in soil showed that the production of $\mathrm{N}_{2} \mathrm{O}$ is reasonably prolific (concentrations of 1 to 30 times the atmospheric concentration). This suggests that $\mathrm{N}_{2} \mathrm{O}$ is produced but cannot diffuse to the soil surface, either because denitrification is complete and $\mathrm{N}_{2}$ is produced or because the $\mathrm{N}_{2} \mathrm{O}$ is nitrified before diffusing. Microporosity in the upper layer needs to be studied further to understand better the diffusion and compaction conditions in these soils (Yamulki and Jarvis, 2002). Samples were taken immediately after fertilisation (November, December and January). After fertilisation, a higher variability in fluxes may occur, which agrees with the general principle that fertilisation increases the emissions of $\mathrm{N}_{2} \mathrm{O}$ due to a higher availability of organic $\mathrm{N}$ (Weitz et al., 2001). Further measurements of potential denitrification are necessary to understand better the capacity of this particular soil to produce and emit $\mathrm{N}_{2} \mathrm{O}$.

Six et al. (2004) recognised that few studies have reported $\mathrm{CH}_{4}$ flux differences between DMC and no-tillage systems and that all those that have, have found a significant enhancement of $\mathrm{CH}_{4}$ uptake with the adoption of DMC (on average $0.6 \mathrm{~kg} \mathrm{ha}^{-1} \mathrm{yr}^{-1}$ ). Preliminary results obtained in the Cerrado region near Rio Verde confirm this observation. $\mathrm{CH}_{4}$ fluxes were analysed in November 2003 and January 2004 in 3 DMC systems aged 9, 11 and 13 years, respectively, and a conventional tillage system. Preliminary results showed $\mathrm{CH}_{4}$ absorption for all treatments, but higher absorption in the DMC systems. $\mathrm{CH}_{4}$ sinks in the conventional tillage were 3.8 and $4.8{\mathrm{~g} \mathrm{C}-\mathrm{CH}_{4}}_{4} \mathrm{ha}^{-1} \mathrm{~d}^{-1}$ in November and January, respectively, whereas they varied between 8 and $16 \mathrm{~g} \mathrm{C}_{-} \mathrm{CH}_{4} \mathrm{ha}^{-1} \mathrm{~d}^{-1}$ in

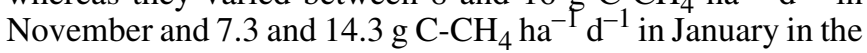
DMC systems. In order to obtain a complete picture, data need to be collected throughout the entire cropping cycle. Only then can any general conclusions be drawn.

\subsection{Carbon budgets at the farm level}

Several studies in Brazil have shown that no-tillage systems are fuel-efficient compared with conventional systems. For example, Landers (2001) reported fuel consumption by a farmers' cooperative in Planaltina (Goías State) (covering 2270 ha) over a six-year period. During this period the land was converted from $100 \%$ conventional tillage, in the agricultural year $92 / 93$, to $100 \%$ no-tillage in the agricultural year 1997/98. The total number of hours that tractors were used was 10630 in $1992 / 93$ and 5135 in 1997/98, showing a decrease in fuel con- sumption of $\sim 50 \%$. Landers (2001) also noted that the number of machine operators was reduced to almost half, freeing up previous machine operators for employment in new farm enterprises. Studies on pesticide use in conventional tillage and DMC systems and resulting on-farm and off-farm emissions of greenhouse gases are lacking, highlighting an area that needs further investigation.

\section{EROSION UNDER NO-TILLAGE AND CONVENTIONAL TILLAGE}

Land degradation, caused by water-induced soil erosion, is a major threat to sustainable agricultural land use, causing serious and costly environmental deterioration. Pimentel et al. (1995) estimated the worldwide cost of soil erosion to be ca. US\$ 400 billion per year. According to Laflen and Roose (1998), water-induced soil erosion is a threat to the long-term sustainability of mankind in all regions of the globe. In the tropics, Lal (1995) estimated that the total transport or movement of carbon displaced by soil erosion is $1.59 \mathrm{Pg} \mathrm{yr}^{-1}$. According to Lal, this estimate ranges from a low of $0.80 \mathrm{Pg} \mathrm{yr}^{-1}$ to a high of $2.40 \mathrm{Pg} \mathrm{yr}^{-1}$. However, only a fraction of soil moved from its original place is transported out of the watershed. The delivery ratio for tropical watersheds may be as low as $10 \%$. This implies that as much as $0.16 \mathrm{Pg} \mathrm{C} \mathrm{yr}^{-1}$ may be transported out of tropical watersheds with a range of 0.08 to $0.24 \mathrm{Pg} \mathrm{C} \mathrm{yr}^{-1}$.

In Brazil, almost every region has problems related to soil erosion. According to De Maria (2004), no-tillage reduces runoff and soil loss by approximately 70 and 90\%, respectively. In order to reduce soil erosion rates, some Brazilian farmers have adopted appropriate farming systems, such as the use of cover crops, mixed crop rotations and conservation tillage. Conservation tillage systems have been developed as an alternative to conventional mouldboard ploughing, to reduce not only water but also wind erosion and to maintain and/or increase soil organic carbon contents (Six et al., 2002). These practices manage litter and crop residues with minimum and no-tillage. Keeping a mulch of crop residues protects the soil surface against raindrop impact, decreases evaporation, increases water storage, reduces production costs and slows down decomposition of soil organic carbon (Rosell and Galantini, 1997).

It has been reported (Bajracharya et al., 1998; Lal, 1995, 1997) that while deposition of eroded soil does not necessarily lead to the direct accumulation of carbon, it is likely to increase the overall sequestration of soil organic carbon by leading to an accumulation of organic material which has a greater potential to be converted into the stable form of soil organic carbon. Depositional and non-eroded areas increase potential accumulation of soil organic carbon, possibly by providing favourable conditions for aggregation. Carbon accumulation in soil seems to occur within aggregates. The above authors concluded that erosion is likely to lead to a gradual depletion of soil organic carbon by exposing the stable carbon pool in micro-aggregates in the soil surface and the subsoil, to processes of degradation by disrupting macro-aggregates and removing successive layers of soil. 


\section{CONCLUSION}

Caution must be taken when analysing DMC systems in terms of carbon sequestration. Comparisons should not be limited solely to carbon storage in the soil but should include a consideration of associated trace gas fluxes. Associated fluxes of methane and nitrous oxide may change the final balance of $\mathrm{C}-\mathrm{CO}_{2}$ equivalents, based on the global warming potential of each gas. Most preliminary results tend to indicate that the adoption of DMC in Brazil is a promising strategy for mitigating carbon emissions to the atmosphere. Since the 1970s, DMC systems have been taken up by farmers in Brazil for a variety of reasons irrespective of carbon sequestration benefits. Therefore the use of DMC systems in Brazil is a good potential strategy for mitigating greenhouse gas emissions as the uptake of DMC is not dependent on carbon markets or political incentives.

Acknowledgements: Research work that lead to this publication was supported partly by the Fond Français pour 1'Environnement Mondial (FFEM-Agroécologie), Conselho Nacional de Desenvolvimento Científico e Tecnológico (CNPq), Fundação de Amparo a Pesquisa do Estado de São Paulo (Fapesp), French Ministry of Foreign Affairs (MAE) Fundação Agrissus and The Global Environmental Facility (Project No. GFL-2740-0243-81). We also would like to thank E. Roose for being given the opportunity to present and write up this work for the Symposium "Land-Use, Carbon Sequestration and Erosion".

\section{REFERENCES}

Amado T.J., Fernandez S.B., Mielniczuk J. (1998) Nitrogen availability as affected by ten years cover crop and tillage systems in southern Brazil, Braz. J. Soil Water Conserv. 5, 268-271.

Amado T.J., Pontelli C.B., Júnior G.G., Brum A.C.R., Eltz F.L.F., Pedruzzi C. (1999) Seqüestro de carbono em sistemas conservacionistas na Depressão Central do Rio Grande do Sul, in: Reunião bienal da rede latino-americana de agricultura conservacionista, Universidade Federal de Santa Catarina, Florianópolis, Brazil, pp. 42-43.

Amado T.J., Bayer C., Eltz F.L.F., Brum A.C.R. (2001) Potencial de culturas de cobertura em acumular carbono e nitrogênio no solo no plantio direto e a melhoria da qualidade ambiental, Rev. Brasil. Ciência Solo 25, 189-197.

Bajracharya R.M., Lal R., Kimble J.M. (1998) Soil organic carbon distribution in aggregates and primary particle fractions as influenced by erosion phases and landscape position, in: Lal R., Kimble J.M., Follett R.F., Stewart B.A. (Eds.), Soil processes and the carbon cycle, Advances in soil science, CRC Press, Boca Raton, pp. 353367.

Bayer C., Bertol I. (1999) Caracteristicas quimicas de um cambissolo humico afetadas por sistemas de preparo, com ênfase a matéria orgânica, Rev. Brasil. Ciência Solo 23, 687-694.

Bayer C., Martin-Neto L., Mielniczuk J., Ceretta C.A. (2000a) Effect of no-till cropping systems on soil organic matter in a sandy clay loam Acrisol from southern Brazil monitored by electron spin resonance and nuclear magnetic resonance, Soil Till. Res. 53, 95-104.

Bayer C., Mielniczuk J., Amado T.J.C., Martin-Neto L., Fernandes S.V. (2000b) Organic matter storage in a sandy clay loam Acrisol affected by tillage and cropping systems in southern Brazil, Soil Till. Res. 54, 101-109.

Bayer C., Mielniczuk J., Martin-Neto L., Ernani P.R. (2002) Stocks and humification degree of organic matter fractions as affected by notillage on a subtropical soil, Plant Soil 238, 133-140.

Bernoux M., Feller C., Cerri C.C., Eschenbrenner V., Cerri C.E.P. (2005) Soil carbon sequestration, in: Roose E., Lal R., Feller C.,
Barthès B., Stewart B. (Eds.), Soil Erosion \& Carbon Dynamics, Advances in Soil Science, CRC Publisher, Boca Raton, pp. 13-22.

Borges Filho E.P. (2001) O desenvolvimento do plantio direito no Brasil: a conjunção de interesses entre agricultores, indústrias e estado, Master Thesis, UNICAMP/IE, Campinas, Brazil, 141 p.

Cambardella C.A., Elliott E.T. (1992) Particulate soil organic matter changes across a grassland cultivation sequence, Soil Sci. Soc. Am. J. 56, 777-783.

Castro Filho C., Muzilli O., Podanoschi A.L. (1998) Estabilidade dos agregados e sua relação com o teor de carbono orgânico num Latossolo Roxo distrófico, em função de sistemas de plantio, rotação de culturas e métodos de preparo das amostras, Rev. Brasil. Ciência Solo 22, 527-538.

Castro Filho C., Lourenço A., Guimarães M. de F., Fonseca I.C.B. (2002) Aggregate stability under different soil management systems in a red latosol of Paraná, Brazil, Soil Till. Res. 65, 45-51.

Corazza E.J., Silva J.E., Resck D.V.S., Gomes A.C. (1999) Comportamento de diferentes sistemas de manejo como fonte e depósito de carbono em relação a vegetação de Cerrado, Rev. Brasil. Ciência Solo $23,425-432$.

De Maria I.C. (2004), Plantio Direto, ww.iac.sp.gov.br/Arquivos/Noticias/Anteriores/Materias/PlantioDireto.htm.

De Maria I.C., Nnabude P.C., Castro O.M. (1999) Long-term tillage and crop rotation effects on soil chemical properties of a Rhodic Ferralsol in southern Brazil, Soil Till. Res. 51, 71-79.

Derpsch R. (2001) Conservation Tillage, No-tillage and related technologies, in: García-Torres L., Benites J., Martínez-Vilela A. (Eds.), Conservation Agriculture, a Worldwide Challenge, Proceedings of the First World Congress on Conservation Agriculture, Madrid, 15 October, 2001, Vol. 1, pp. 161-170, http://www.rolf-derpsch.com.

Dick W.A., Durkalski J.T. (1997) No-tillage production agriculture and carbon sequestration in a Typic Fragiudalf soil of Northeastern Ohio, in: Lal R., Kimble J., Follett R.F., Stewart B.A. (Eds.), Management of carbon sequestration in soil, Advances in soil science, CRC Lewis Publishers, Boca Raton, pp. 59-71.

Febrapdp, Federação Brasileira de Plantio Direto na Palha (2004), http://www.febrapdp.org.br.

Flessa H., Ruser R., Dörsch P., Kamp T., Jimenez M.A., Munch J.C., Beese F. (2002) Integrated evaluation of greenhouse gas emissions $\left(\mathrm{CO}_{2}, \mathrm{CH}_{4}, \mathrm{~N}_{2} \mathrm{O}\right)$ from two farming systems in southern Germany, Agr. Ecosyst. Environ. 91, 175-189.

Freixo A.A., Machado P.L.O.A., dos Sandos H.P., Silva C.A., Fadigas F.S. (2002) Soil organic carbon and fractions of a Rhodic Ferralsol under the influence of tillage and crop rotation systems in southern Brazil, Soil Till. Res. 64, 221-230.

Giller K.E., Cadisch G., Palm C. (2002) The North-South divide! Organic wastes, or resources for nutrient management? Agronomie 22, 703-709.

Houghton R.A. (2003) Why are estimates of the terrestrial carbon balance so different? Global Change Biol. 9, 500-509.

Karlen D.L., Cambardella C.A. (1996) Conservation strategies for improving soil quality and organic matter storage, in: Carter M.R., Stewart B.A. (Eds.), Structure and Organic Matter Storage in Agricultural Soils, Advances in Soil Science, CRC Press, Boca Raton, pp. 395-420.

Kladivko E. (2001) Tillage systems and soil ecology, Soil Till. Res. 61, 61-76.

Laflen J.M., Roose E.J. (1998) Methodologies for assessment of soil degradation due to water erosion, in: Lal R., Blum W.H., Valentin C., Stewart B.A. (Eds.), Methods for assessment of soil degradation, Advances in Soil Science, CRC Press, Boca Raton, pp. 3155 .

Lal R. (1995) Global soil erosion by water and carbon dynamics, in: Lal R., Kimble J., Levine E., Stewart B.A. (Eds.), Soils and global change, Advances in soil science, CRC Lewis Publishers, Boca Raton, pp. 131-142. 
Lal R. (1997) Residue management, conservation tillage and soil restoration for mitigating greenhouse effect by $\mathrm{CO}_{2}$-enrichment, Soil Till. Res. 43, 81-107.

Lal R. (1998) Soil processes and the greenhouse effect, in: Lal R., Blum W.H., Valentin C., Stewart B.A. (Eds.), Advances in Soil Science, CRC Press, Boca Raton, pp. 199-212.

Lal R. (2002) Soil carbon dynamic in cropland and rangeland, Environ. Pollut. 116, 353-362.

Lal R., Kimble J., Follet R. (1997) Land use and soil C pools in terrestrial ecosystems, in: Lal R., Kimble J., Follett R.F., Stewart B.A. (Eds.), Management of carbon sequestration in soil, Advances in soil science, CRC Lewis Publishers, Boca Raton, pp. 1-10.

Lal R., Kimble J., Follett R., Cole C.V. (1998) The potential of U.S. Cropland to sequester carbon and mitigate the greenhouse effect, Ann Arbor Press, Ann Arbor, USA, 1998.

Landers J.N. (2001) Zero tillage development in tropical Brazil: The story of a successful NGO activity, FAO Agricultural Services Bulletin 147, Rome, (available on line at www.fao.org/DOCREP/ 004/Y2638E/y2638e00.htm\#toc).

Lima V.C., Lima J.M.C., Eduardo B.J.P., Cerri C.C. (1994) Conteúdo de carbono e biomassa microbiana em agrosistemas: comparação entre métodos de preparo do sols, Agrárias Curitiba 13, 297-302.

Lindstrom M.J., Schumacher T.E., Cogo N.P., Blecha M.L. (1998) Tillage effects on water runoff and soil erosion after sod, J. Soil Water Conserv. 53, 59-63.

Machado P.L.O.A., Silva C.A. (2001) Soil management under no-tillage systems in the tropics with special reference to Brazil, Nutr. Cycl. Agroecosys. 61, 119-130.

Metay A. (2004) Influence of no-tillage and cover plants on $\mathrm{N}_{2} \mathrm{O}$ production and emission from soils in the Cerrados (Brazil), International conference on greenhouse gas emissions from agriculture, mitigations options and strategies, Leipzig, Germany, February 2004, Congress communications.

Passianoto C.C., Ahrens T., Feigl B.J., Steudler P.A., Carmo J.B., Melillo J.M. (2003) Emissions of $\mathrm{CO}_{2}, \mathrm{~N}_{2} \mathrm{O}$ and $\mathrm{NO}$ in conventional and no-till management practices in Rondônia, Brazil, Biol. Fert. Soils 38, 200-208.

Paustian K., Six J., Elliott E.T., Hunt H.W. (2000) Management options for reducing $\mathrm{CO}_{2}$ emissions form agricultural soils, Biogeochemistry $48,147-163$.

Peixoto R.T., Stella L.M., Machulek Junior A., Mehl H.U., Batista E.A. (1999) Distibução das frações granulométricas da matéria orgânica em função do manejo do sols, in: Anais 3o Encontro brasileiro sobre substâncias húmicas, Santa Maria, Brazil, pp. 346348 .

Perrin A.S. (2003) Effets de différents modes de gestion des terres agricoles sur la matière organique et la biomasse microbienne en zone tropicale humide au Brésil, Master Dissertation, École Polytechnique Fédérale de Lausanne, Lausanne, Switzerland, 68 p.

Pimentel D., Harvey C., Resosudarmo P., Sinclair K., Kurz D., McNair M., Crist S., Shpritz L., Fitton L., Saffouri R., Blair R. (1995) Environmental and economic costs of soil erosion and conservation benefits, Science 267, 1117-1123.

Pinto A.S., Bustamante M.M.C., Kisselle K., Burke R., Zepp R., Viana L.T., Varella R.F., Molina M. (2002) Soil emissions of $\mathrm{N}_{2} \mathrm{O}$, NO and $\mathrm{CO}_{2}$ in Brazilian Savannas: effects of vegetation type, seasonality and prescribed fires, J. Geophys. Res. 107 (D20) 8089, doi:10.1029/2001JD000342.

Plataforma Plantio Direto (2003) http://www.embrapa.br/plantiodireto (11/02/2003).

Reicosky D.C., Kemper W.D., Langdale G.W., Douglas C.L., Rasmunssen P.E. (1995) Soil organic matter changes resulting from tillage and biomass production, J. Soil Water Conserv. 50, 253-261.

Resck D.V.S., Vasconcellos C.A., Vilela L., Macedo M.C.M. (2000) Impact of conversion of Brazilian Cerrados to cropland and pastureland on soil carbon pool and dynamics, in: Lal R., Kimble J.M., Stewart B.A. (Eds.), Global climate change and tropical eco- systems, Advances in Soil Science, CRC Press Boca Raton, pp. 169-196.

Riezebos H.T.H., Loerts A.C. (1998) Influence of land use change and tillage practice on soil organic matter in southern Brazil and eastern Paraguay, Soil Till. Res. 49, 271-275.

Roscoe R., Buurman P. (2003) Tillage effects on soil organic matter in density fractions of a Cerrado Oxisol, Soil Till. Res. 70, 107-119.

Rosell R.A., Galantini J.A. (1997) Soil organic carbon dynamics in native and cultivated ecosystems of South America, in: Lal R., Kimble J., Follett R.F., Stewart B.A. (Eds.), Management of carbon sequestration in soil, Advances in soil science, CRC Lewis Publishers, Boca Raton, pp. 11-33.

Sá J.C.M. (2001) Dinâmica da matéria orgânica do solo em sistemas de manejo convencional e plantio direto no estado do Paraná, $\mathrm{PhD}$ Thesis, Escola Superior de Agricultura Luiz de Queiroz, Universidade de São Paulo, Piracicaba.

Sá J.C.M., Cerri C.C., Lal R., Dick W.A., Venzke Filho S.P., Piccolo M.C., Feigl B. (2001) Organic matter dynamics and carbon sequestration rates for a tillage chronosequence in a Brazilian Oxisol, Soil Sci. Soc. Am. J. 65, 1486-1499.

Schuman G.E., Janzen H.H., Herrick J.E. (2002) Soil carbon dynamics and potential carbon sequestration by rangelands, Environ. Pollut. 116, 391-396.

Scopel E., Doucene E., Primot S., Douzet J.M., Cardoso A., Feller C. (2003) Diversity of direct seeding mulch based cropping systems (DMC) in the Rio Verde region (Goias, Brazil) and consequences on soil carbon stocks, Book of Extended Summary of the II World Congress on Conservation Agriculture, Vol. II, 11-15 August 2003, Foz do Iguaçu, Brazil, pp. 286-289.

Siqueira Neto M. (2003) Estoques de carbono e nitrogênio do solo e emissões de gases do efeito estufa no sistema plantio direto em Tibagi (PR), Master Dissertation, University of São Paulo, Piracicaba, Brazil.

Sisti C.P.J., dos Santos H.P., Kohhann R., Alves B.J.R., Urquiaga S., Boddey R.M. (2004) Change in carbon and nitrogen stocks in soil under 13 years of conventional or zero tillage in southern Brazil, Soil Till. Res. 76, 39-58.

Six J., Elliott E.T., Paustian K. (1999) Aggregate and soil organic matter dynamics under conventional and no-tillage systems, Soil Sci. Soc. Am. J. 63, 1350-1358.

Six J., Feller C., Denef K., Ogle S.M., Sa J.C.M., Albrecht A. (2002) Soil organic matter, biota and aggregation in temperate and tropical soils - effects of no-tillage, Agronomie 22, 755-775.

Six J., Ogle S.M., Breidt F.J., Conant R.T., Mosier A.R., Paustian K. (2004) The potential to mitigate global warming with no-tillage management is only realized when practices in the long term, Global Change Biol. 10, 155-160.

Testa V.M., Teixeira L.A.J., Mielniczuk J. (1992) Características químicas de um podzólico vermelho escuro afetada por sistemas de culturas, Rev. Brasil. Ciência Solo 16, 107-114.

Venzke Filho S.P., Siqueira Neto M., Piccolo M.C., Feigl J., Cerri C.C. (2002) Características químicas do solo em função do tempo de adoção do sistema plantio direto, in: FERTIBIO - Agricultura: Bases ecológicas Para o desenvolvimento social e econômico sustentado, Rio de Janeiro, Brazil.

Weitz A.M., Linder E., Frolking S., Crill P.M., Keller M. (2001) $\mathrm{N}_{2} \mathrm{O}$ emissions from humid tropical agricultural soils: effects of soil moisture, texture and nitrogen avaibility, Soil Biol. Biochem. 33, 1077-1093.

Yamulki S., Jarvis S.C. (2002) Short-term effects of tillage and compaction on nitrous oxide, nitric oxide, nitrogen dioxide, methane and carbon dioxide fluxes from grassland, Biol. Fert. Soils 36, 224231.

Zotarelli L., Alves B.J.R., Urquiaga S., Torres E., Paustian K., Boddey R.M., Six J. (2003) Efeito do preparo do solo nos agregados do solo e no conteúdo de matéria orgânica, in: XXXIV Congresso Brasileiro de Ciência do Solo, Ribeirão Preto, Brazil. 